\title{
STATE JURISDICTION TO TAX INCOMES
}

\author{
J. Mark JaCOBSon $\dot{\dagger}$ \\ I
}

Ever since the decision of the United States Supreme Court in Farmers Loan and Trust Company v. Minnesota, ${ }^{1}$ conjecture and discussion have been rife concerning state jurisdiction to tax income. ${ }^{2}$ Prior to I93o multiple state taxation had been recognized in both legal theory and administrative practice. If a state were in a position to render the taxpayer or his property some benefit, regardless of its remoteness, the courts deemed it reasonable that the taxpayer contribute to its support. This dependence of tax jurisdiction upon potential benefit or protection rendered immaterial the consideration that some other state might confer greater benefit or more complete protection and might thus be more justified in its demand for financial contribution. Liability to taxation in one state, the Supreme Court had repeatedly enunciated, did not necessarily exclude liability in another; and exemption from double taxation was not guaranteed by the Fourteenth Amendment. ${ }^{3}$

Especially toward state income taxation, then still in the experimental stage of fiscal legislation, the Court had, in none too clear analyses of its nature, ${ }^{4}$ proven highly tolerant. In Shaffer $v$. Carter ${ }^{5}$ it had sustained a state income tax upon the net income of a non-resident derived from oil wells within the taxing state. In Travis $v$. Yale \& Towne Manufacturing Company ${ }^{6}$ it had held that a state may tax the salaries earned there by nonresidents. In United States Glue Company v. Oak Creek ${ }^{7}$ it had declared valid a state income tax upon the net proceeds derived in part from interstate commerce. In Maguire $v$. Trefry ${ }^{8}$ it had held that a resident beneficiary

† A. B., M. A., I926, Ph. D., I929, Brown University; IL. B., I934, Yale University; member of the New York bar; author of Developarent of AMrericaN Political ThoughT -A Documentary History (I932), and of numerous articles in legal periodicals.

I. 280 U. S. 204 (I930).

2. Harding, Double Taxation of Property and Income (1933) ; Stimson, JurisdicTION AND PowER OF TAXation (1933); Lowndes, State Jurisdiction to Tax Income (I932) 6 TeMr. L. Q. 486; Merrill, Jurisdiction to Tax-Another Word (1935) 44 Y ALE L. J. 582; Rottschaefer, State Jurisdiction of Income for Tax Purposes (r93I) 44 HARv. L. Rev. I075. 3. Blackstone v. Miller, I88 U. S. I89 (I903) ; Kidd v. Alabama, I88 U. S. 730 (Ig03); Fidelity \& Columbia Trust Co. v. Louisville, 245 U. S. 54 (I9I7) ; Cream of Wheat Co. v. Grand Forks, 253 U. S. 325 (1920).

In the case of land and tangible personalty, the Court had already, within the protection theory, limited double taxation. Situs rather than domicile was made the basis for taxation. See Louisville \& Jeffersonville Ferry Co. v. Kentucky, I88 U. S. 385 (1903); Delaware, L. \& W. R. R. v. Pennsylvania, Ig8 U. S. 34I (I905) ; Union Refrigerator Transit Co. v. Kentucky, I99 U. S. I94 (I905) ; Selliger v. Kentucky, 2I3 U. S. 200 (I909) ; Union Tank Line Co. v. Wright, 249 U. S. 275 (I9Ig); Wallace v. Hines, 253 U. S. 66 (Ig20).

4. Brown, The Nature of the Income Tax (1933) I7 Mrn. L. Rev. I27.

5. 252 U. S. 37 (I920). Cf. Lake Superior Mines v. Lord, 27 I U. S. 577 (I926).

6. 252 U. S. 60 (1920).

7. 247 U. S. 321 (I9I8).

8. 253 U. S. I2 (I920). 
of a foreign administered trust of intangibles might be taxed upon the income received from the trust estate.

Then came a reversal of jurisdictional tax concepts by the Supreme Court. In Farmers Loan and Trust Company $v$. Minnesota ${ }^{9}$ a New York resident had died leaving at his domicile negotiable bonds and certificates of indebtedness issued by the state of Minnesota and its municipalities. Both New York and Minnesota imposed an inheritance tax upon those securities. The United States Supreme Court vigorously attacked double taxation and denied, upon the basis of the due process clause, Minnesota's jurisdiction to tax. It is not permissible under the Fourteenth Amendment, the Court emphasized, for two states to have power to tax the same personalty on different and inconsistent principles.

"And, we think, the general reasons declared sufficient to inhibit taxation of them [tangibles] by two States apply under present circumstances with no less force to intangibles with taxable situs imposed by due application of the legal fiction [mobilia sequuntur personam]. Primitive conditions have passed; business is now transacted on a national scale. A very large part of the country's wealth is invested in negotiable securities whose protection against discrimination, unjust and oppressive taxation, is matter of the greatest moment." 10

In the fields of property ${ }^{11}$ and inheritance ${ }^{12}$ taxation, the Court was quick to expand its new doctrine. Exclusive tax jurisdiction now rested upon the business situs of the property, or, in the absence of proof thereof, upon the domicile of the owner. From I930 to the present session of the Court, only a single case arose involving potential double taxation of income. And there both the facts and the grounds employed by the taxpayer to oppose the tax rendered the Court's decision indecisive. In Lazerence v. State Tax Commission ${ }^{13}$ a domiciliary state, taxing a resident's income, included profits from road-building in another state. The taxpayer failed to present evidence that his business situs was elsewhere than at his domicile (that is, that his foreign road-building activities were not part and parcel of his local business) and endeavored to argue that the tax was merely an excise or occupation tax and could not be applied to his activities in another state. In sustaining the tax, the Court merely decided that the domiciliary state could tax income from personal activities performed elsewhere. Whether incomes other than from personal services could be subjected to double taxation, the

9. 280 U. S. 204 (I930).

I0. Id. at $2 \mathrm{II}$.

II. Safe Deposit \& Trust Co. v. Virginia, 280 U. S. 83 (I929); Baldwin v. Missouri, 28 I U. S. 586 (I930); Beidler v. South Carolina, 282 U. S. I (1930); Senior v. Braden, 295 U. S. 422 (I935); Wheeling Steel Corp. v. Fox, 298 U. S. I93 (I936).

12. First Nat'l Bank v. Maine, 284 U. S. 312 (1932); City Bank Farmers' Trust Co. v. Schnader, 293 U. S. II2 (I934).

I3. 286 U. S. 276 (I932). 
opinion did not indicate. And the vigorous dissents of legal commentators seemed to undermine the Court's reasoning. ${ }^{14}$

In the parallel field of state income tax jurisdiction-state taxation of incomes of federal instrumentalities or of their employees-the Supreme Court had, prior to the present term, similarly upset the apple-cart of judicial precedent. This time, however, in Helvering $v$. Powers, ${ }^{15}$ it had seemed to open new reservoirs for state income taxation. The state of Massachusetts had taken over the Boston Elevated Railway Company, a private corporation, for an indefinite period of public operation and had set up a board of trustees, appointed by the governor and his counsel, to manage the properties and to fix the utilityl rates. Although the trustees received their compensation from the company rather than directly from the state, the state guaranteed the deficits of the company, and the usual status of finances was that the company did not earn sufficient revenues to meet all its obligations. The Court denied to the trustees immunity, as to their salaries, from federal income taxes. The non-governmental, proprietary nature of the business enterprise gave the Federal Government the right to tax the salaries of the enterprise's employees and officials. The Court by way of dictum announced that if the state itself had acquired the property of the utility company and had operated it as a purely government-owned project, federal taxation would still be constitutional as to both the business and the salaries of the state employees engaged therein. Inasmuch as the Court had established in Collector $v$. Day ${ }^{16}$ that the same constitutional doctrines were applicable to state taxation of federal instrumentalities as were true of federal taxation of state instrumentalities, it would seem obvious that now the states would be free to tax the salaries of federal employees engaged in proprietary activities and possibly even the profits of the ever-increasing number of corporations owned by the federal government.

Such was the uncertain status at the end of 1936 of state jurisdiction to tax incomes. Early in I937, however, three decisions were handed down by the Supreme Court-Whitney v. Graves, ${ }^{17}$ Cohn v. Graves, ${ }^{18}$ and Rogers v. Graves ${ }^{19}$ - which have done much to clarify these doubts. The first two, dealing with the tax relationship between states, greatly expanded the states' taxing jurisdiction, sanctioned double income taxation, and contained implications important for a radical revision of state income tax planning. The last, dealing with the tax relationship between the state and federal governments, cut deeply into the sources of state revenues-a cut especially deep

I4. HARDING, op. cit. supra note 2; Rottschaefer, supra note 2.

I5. 293 U. S. 214 (I934).

I6. II Wall. II3 (U. S. I87I).

I7. 57 Sup. Ct. 237 (I937).

I8. 57 Sup. Ct. 466 (I937), 85 U. of PA. L. Rev. 645.

Ig. 57 Sup. Ct. 269 (1937). 
in the light of the now constant expansion of the national government into such business projects as the sale of hydro-electric power, the lending of money to industries and home owners, and the construction of large housing units.

An analysis and comparison of these three decisions demonstrate their lack of logical consistency. The Court has isolated the problems of state income tax jurisdiction into narrow and unrelated pigeonholes. Although it has endeavored to be internally consistent in its treatment of the problems in each pigeonhole, it has apparently viewed each truly related problem through a distinct set of logico-legal spectacles ground from differently colored symbols. When the question concerns domiciliary taxation of incomes earned elsewhere, the current catch-phrase is "protection". Where a nondomiciliary state attempts to tax incomes earned by non-residents within the state, the reasoning is grooved into the amorphous concept of "situs". And when a state seeks revenue from federal employees, the symbol of "national freedom from state inference" blocks the tax collector. Except in the last category of cases, the Supreme Court undoubtedly is desirous of preserving state revenue sources in these days of constantly expanding governmental needs. To prevent interference with the highly practical task of collecting taxes necessary to run the state governments, the justices, trained in legal tradition and yearning to be rational, have rationalized their positive actions by recourse to remote, untested, yet comforting bundles of abstract symbols. ${ }^{20}$ It matters not apparently that their rationalizations smack of pluralistic legalism rather than monistic logic; nor that their pragmatism harnesses one watershed for state revenues and diverts beyond state reach an even more desirable stream of taxation.

\section{II}

The case of Whitney $v$. Graves ${ }^{21}$ went far in removing doubts as to the right of a state to collect a portion of the income accruing to non-residents from property or business activities within the state. Here the problem specifically grew out of the sale of a New York Stock Exchange membership. The New York Stock Exchange is an unincorporated voluntary New York association, limited in its membership and governed by its own constitution, by-laws, and rules, and supported by dues and charges paid by its members. Membership or a "seat" on the Exchange carries with it valuable privileges; a member may buy or sell securities at a commission substantially less than that charged to a non-member. ${ }^{22}$ Members conducting brokerage businesses in cities other than New York can thus cut their security buying and selling costs by telegraphing their orders to Exchange member corre-

20. See Arnold, Symbols in Government (r935).

2I. 57 Sup. Ct. 237 (I937).

22. Meyer, The Law of Stock Brokers and Stock Exchanges (I93I) 13-16, 75-9. 
spondents in New York. In I929 the Exchange increased its membership and entitled each member to one-quarter of a new "seat". The taxpayer, a resident of Massachusetts and a member of the Exchange on behalf of a Boston brokerage firm, sold his right. The New York Tax Commission assessed against him an income tax upon the profits of the sale, calculated at the difference between the proceeds of the sale and the original cost together with contributions paid to the Exchange in the form of dues. The taxpayer, after paying under protest, petitioned the commission for a refund. The state courts ${ }^{23}$ sustained the commission in its rejection of the petition and appeal was taken to the United States Supreme Court upon the ground that the tax assessment contravened the Fourteenth Amendment "as an extraterritorial tax".

In holding the tax valid, the Supreme Court, in a unanimous opinion by Mr. Chief Justice Hughes, placed the total emphasis upon the situs in New York of the Stock Exchange. Since the taxpayer's profit was derived from the sale of property peculiar to New York, New York is entitled to a share of the proceeds.

"When we speak of a 'business situs' of intangible property in the taxing State we are indulging in a metaphor. We express the idea of localization by virtue of the attributes of the intangible right in relation to the conduct of affairs at a particular place. The right may grow out of the actual transactions of a localized business or the right may be identified with a particular place because the exercise of the right is fixed exclusively or dominantly at that place." 24

"We think that the dominant attribute of relator's membership in the New York Stock Exchange so links it to the situs of the Exchange as to localize it at that place and hence to bring it within the taxing power of New York. Accordingly, we hold that in laying the tax upon the profits derived by the relator from the sale of the right appurtenant to his membership the State did not exceed the bounds of its jurisdiction." 25

Certain language of the Court would seem to indicate by implication that New York alone could levy the income tax here involved, that double taxation of incomes from such transactions would henceforth fall under the ban of Farmers Loan and Trust Company v. Minnesota, and that such double taxation was to be prevented by exclusive reference to the concept of "situs". In reply to the argument that in Citizens National Bank v. Durr ${ }^{26}$ the Court had held that a membership in the New York Stock Exchange, owned by a resident of Ohio, was subject to taxation at his domicile, the Chief Justice

23. 246 App. Div. 652, 283 N. Y. Supp. 2I9 (3d Dep't, I935), aff'd, 27I N. Y. 594, 3 N. E. (2d) 201 (1936).

24. 57 Sup. Ct. 237,238 (1937).

25. Id. at 239.

26. 257 U. S. 99 (I92I). 
declared that "what the Court said with respect to double taxation must be read in the light of the decisions in Farmers' Loan \& Trust Co. v. Minnesota and later cases upon that point." 27 The Cohn case, however, demonstrates that these conjectures are erroneous, that "situs" is not the sole test of state income tax jurisdiction, and that double taxation of incomes is not taboo. The meaning of the Court's remarks must remain in the dark pit of superfluous legal verbiage possibly to be illuminated some day by judicial exigesis.

The case of Cohn v. Graves ${ }^{28}$ is, in many respects, the converse of the Whitney case. Whereas the latter goes far in determining the right of a state to tax incomes of non-residents from local sources, the former emphasizes the right of a state to tax incomes of residents from foreign sources. Whereas the legal focus in the Whitney case is the situs of the source of the taxpayers' income, in the Cohn case it is the domicile of the taxpayer.

In rgr 3 the taxpayer's husband died a resident of New Jersey and devised to her the net income from the major portion of his estate during her widowhood. ${ }^{29}$ During the years I93I and I932, when she was domiciled in New York, her income received from her husband's estate was derived in part from rents from New Jersey realty and interest from mortgages on New Jersey realty. The estate since her husband's death had been administered in New Jersey through a New Jersey office by executors who were residents of New Jersey. The bonds and mortgages of the estate were physically kept in a New Jersey safe deposit box. The fiduciaries managed the properties, collected the rents and the interest and amortization payments on the bonds and mortgages, reinvested the proceeds in New Jersey, and received an annual compensation for their services. In 1933 the New York courts in Pierson v. Lynch ${ }^{30}$ held that New York could not levy an income tax on foreign rents. Accordingly in April, 1934, the taxpayer applied to the State Tax Commission for refunds. The Commission notified her that claims for refunds were being held in abeyance pending an appeal of the Pierson case to the United States Supreme Court. After the latter tribunal dismissed the certiorari ${ }^{31}$ the Commission notified the taxpayer that it had not yet had sufficient time to determine the full effect of the Pierson decision. In May, I935, however, the state legislature, upon the advice of the Tax Commission, amended the income tax statute by specifically providing that the rental income derived by a resident of New York from real property located outside the state constituted taxable income. ${ }^{32}$ This act, moreover, was made retro-

27. Ibid.

28. 57 Sup. Ct. 466 (I937), 85 U. of PA. L. REv. 645.

29. The facts of the Cohn case, as given by the Court's opinion, are supplemented by the record on appeal.

30. 237 App. Div. 763, 263 N. Y. Supp. 259 (3d Dep't, I933), aff'd, 263 N. Y. 533, I89 N. E. 684 (1933).

3I. 293 U. S. 52 (I934).

32. N. Y. Cons. Laws (Cahill, Supp. I935) c. 6I, § 359. 
active to January I, I9I9. In July, I935, the Commission rejected the appellant's refund claim on the authority of the new amendment. The taxpayer thereupon appealed to the state courts, averring that the statute, in imposing a tax upon a resident on rents and mortgage interest derived from New Jersey real estate, violated her rights under the Fourteenth Amendment. No mention was made, however, of the retroactive application of the amendment. ${ }^{33}$ The Appellate Division by a four-to-one vote reversed the determination of the State Tax Commission, declaring that "under the Fourteenth Amendment of the Federal Constitution it was not within the power of a state, irrespective of the wording of the statute, to tax a resident of the state on account of rentals or income received from land located beyond its borders." 34 On appeal, the Court of Appeals by a four-to-three vote reversed the Appellate Division in a memorandum opinion that merely stated that rents and mortgage interest from foreign realty are taxable income when received by a New York resident and that the court had necessarily passed upon a federal question, ${ }^{35}$ and that made no attempt to analyze the constitutional issues or to harmonize the Pierson decision. The constitutionality of the tax was finally sustained by the United States Supreme Court by a sevento-two vote.

Mr. Justice Stone, speaking for the majority, sustained domiciliary taxation of foreign rentals on the protection theory, which the Court had previously discarded in property and inheritance taxation. "Enjoyment of the privileges of residence in the state and the attendant right to invoke the protection of its laws are inseparable from responsibility for sharing the costs of government." 36 The domiciliary state affords protection to the recipient of the income "in his person, in his right to receive the income and in his enjoyment of it when received." 37 In return, a tax apportioned to the ability of the individual to pay equitably distributes the burdens of government among those who are privileged to enjoy such protection. Inasmuch as the domiciliary state cannot project its police or judicial arms into another state to safeguard its citizens' property, business, or investments there, it necessarily follows that the protection he receives is not protection in his earning the income or even in receiving it outside the state, but rather in his expending it. ${ }^{38}$

A tax on the income from foreign land, the majority held, is so essentially different from a tax on the land itself and affects the land so remotely as not to fall within the jurisdictional prohibition against the taxation of

33. Accordingly, the United States Supreme Court refused to pass upon this issue, even though it was argued before both the Appellate Division and the Court of Appeals.

34. 246 App. Div. 335, 336, 286 N. Y. Supp. 485, 486 (3d Dep't, 1936).

35. $27 \mathrm{I}$ N. Y. 353,3 N. E. (2d) 201 (1936).

36. 57 Sup. Ct. 466,467 (1937).

37. Ibid.

38. This protection theory is conspicuously absent in Rogers v. Graves, discussed infra. 
lands situated outside the state. ${ }^{39}$ The Court here rejected a long line of precedents holding that land and the rents therefrom are inherently so closely related to each other that both are given the same legal incidents and attributes. ${ }^{40}$ This legal conclusion was to a large degree an outgrowth of the recognition by practical economists that land apart from its income can have no value, that real estate value and rents are inseparable. Leading authorities in the field of real estate appraisal state in the broadest terms that the only sound method of determining the value of land is the capitalization of its rent or income. ${ }^{41}$ In Pollock v. Farmers' Loan and Trust Company, ${ }^{42}$ in considering the nature of income taxes, the Court similarly recognized how intrinsically the same are land and its rents. The question there considered was whether a tax on rents was a direct tax within the meaning of the Federal Constitution requiring all direct taxes to be apportioned, and the Court declared that an annual tax upon the annual value or annual user of real estate appeared the same in substance as an annual tax on the real estate, which would be paid out of the rent or income. This interpretation of the Pollock case has been followed by the state courts in passing upon the right of a domiciliary state to levy income taxes on income derived from foreign realty. ${ }^{43}$ In the Cohn case the majority viewed the tax as not upon the property earning the income but rather upon the privilege of the receipt or use of the income within the state. ${ }^{44}$ The Court failed to recognize that the right to income from realty is as much an element of the property concept as is the right to its devolution or transfer. If, accordingly, a tax on its devolution constitutes a tax upon the property, then similarly a tax upon the fruits of the land is in effect a tax upon the land. And if New York may not tax the devolution of land beyond its borders, then it should not be permitted to tax the fruits of the land situate in another state.

Having held that New York could tax its residents upon income secured from New Jersey rents, the Court easily disposed of the taxpayer's contention that her income from interest on bonds, secured by mortgages on New

39. Senior v. Braden, 295 U. S. 422 (I935).

40. See Green v. Biddle, 8 Wheat. (U. S. I823) ; United States v. Noble, 237 U. S. 74 (1915); Scully v. People, I04 Ill. 349 (I882); State v. Royal Mineral Ass'n, I32 Minn. 232, I56 N. W. I28 (Igr6); Farley v. Craig, I5 N. J. L. I90 (I836); Brown v. Brown, 33 N. J. Eq. 650 (I88r) ; Van Wicklen v. Paulson, I4 Barb. 654 (N. Y. 1836); Marshall v. Mosely, 2I N. Y. 280 (I860).

4I. Babcock, Valuation of Real Estate (I932) i29; Ely, Economic Essays in Honor of John Bates Clark (I927) I30; KNiskern, Real Estate Appraisal aNd ValUATTON (I933) 24 I.

42. I57 U. S. 429 , I 58 U. S. 601 (1895).

43. Opinion of the Justices, 220 Mass. 613, 624, I08 N. E. 570, 574 (I915) ; Opinion of the Justices, 84 N. H. 559, 573, I49 Atl. 321, 329 (1930); Pierson v. Iynch, 237 App. Div. 763,263 N. Y. Supp. 259 (3d Dep't, I933), aff'd, 263 N. Y. 533, 189 N. E. 684 (I933), cert. dism'd as intprovidently granted, 293 U. S. 52.

44. The Court rejected the reasoning employed in the instrumentality cases, that a tax on the income thereof is a burden on the instrumentality itself. See Pollock v. Farmers' Loan \& Trust Co., I57 U. S. 429, 485 (I895); Gillespie v. Oklahoma, 257 U. S. 50 I (I922) ; Northwestern Mutual Life Ins. Co. v. Wisconsin, 275 U. S. I36 (1927). 
Jersey land and possessing an alleged "business situs" in New Jersey, should be immune from New York taxation.

"This contention (business situs of investments), if pertinent to the present case, is not supported by the record. . . . The burden rested on the taxpayer to present further facts which would establish a 'business situs'." 45

But even if the facts had spelled out a complete case for business situs in New Jersey, the result obviously would still be unaltered. Surely, no type of property could have a more definite situs outside of New York than New Jersey land; and the Court totally disregarded that factor in granting New York jurisdiction to tax its rent income. Although the Court uses the weasel words "if pertinent to the present case", "46 there is no escape from the conclusion that it intended that the situs of the property or business source of income should in nowise affect the domiliciary state's power to tax.

Inasmuch as the Court had previously held-and did not now reverse or limit that holding - that the state wherein the property producing the income is located may tax the non-resident owner on the net proceeds thereof, the result of the Cohn case, despite the Court's avoidance of this phase of the problem, unavoidably is double taxation. In this it has reversed the trend of the tax decisions that had emphasized the jurisdictional dangers of double taxation, had limited the taxing powers of domiciliary states, and had grounded tax jurisdiction upon the principle of the situs of property. In Safe Deposit \& Trust Company v. Virginia ${ }^{47}$ the Court had held that the domiciliary state of the cestui que trust of an estate consisting of intangible property with situs in another state had no power to tax the cestui upon his interest therein. The adoption of a contrary rule, it was declared, would: "involve possibilities of an extremely serious character by permitting double taxation, both unjust and oppressive." In Farmers Loan and Trust Company $v$. Minnesota ${ }^{48}$ it expressed the same attitude towards double inheritance taxation. So determined was it to destroy the evils of multiple taxation, and to settle the jurisdictional limits of the states' taxing powers that it went to the length of specifically reversing Blackstone v. Miller ${ }^{49}$ which previously lent support to the doctrine that choses in action were subject to taxation at both the debtor's and the creditor's domiciles and that two states might tax, on different and inconsistent principles, the same testamentary transfer of such property. That view, the Court held, inevitably disturbed "good relations among the States" and produced "the kind of

45. Cohn v. Graves, 57 Sup. Ct. 466,469 (I937), 85 U. of PA. L. Rev. 645.

46. Ibid.

47. 280 U. S. 83 (I929).

48. 280 U. S. 204 (I930).

49. I88 U. S. I89 (I903). 
discontent expected to subside after the establishment of the Union." 50 This attitude was reiterated in First National Bank $v$. Maine ${ }^{51}$ and in City Bank Farmers' Trust Company v. Schnader. ${ }^{52}$

To avoid the dangers of multiple taxation, the Court had limited the taxing jurisdiction of domiciliary states. Neither for ad valorem property nor decedent estates taxes does the domiciliary state have jurisdiction to tax a resident on the land or any interest in land situated in another state. ${ }^{53}$ Similarly, it may not tax a resident on tangible personalty which has acquired an actual situs elsewhere. ${ }^{54}$ And even intangible personalty that has acquired an actual situs elsewhere is beyond the taxing power of the domiciliary state. $^{55}$ In so delimiting the jurisdiction of the domiciliary state, the Court had clearly recognized that the doctrine of mobilia sequuntur personam is merely a legal fiction and, as such, must yield to the established fact of the actual presence and control elsewhere of property, tangible or intangible, and ought not to be applied where to do so would result in the injustice of double taxation. ${ }^{56}$

To accomplish the objective of "one thing, one tax", the Court had repeatedly grounded state jurisdiction upon the principle of the situs of property. In Union Refrigerator Transit Company v. Kentucky ${ }^{57}$ it held invalid a Kentucky tax of a domestic corporation upon tangible personalty permanently located and employed elsewhere in the prosecution of its business, and in reaching this decision the Court held that the protection Kentucky afforded to the taxpayer domiciled there was not ground for taxing his personal property that had a situs beyond its borders. ${ }^{58}$ Similarly, if an individual or corporation keeps intangibles-securities, accounts receivable, bank accounts-in a state other than his domicile and if they have acquired a business situs there, then such non-domiciliary state has exclusive tax jurisdiction. ${ }^{59}$ In inheritance tax cases, the Court likewise declared that the right to transmit property at death was so intimate an element of the prop-

50. 280 U. S. 204,209 (I930).

5I. 284 U. S. 3I2, 324 (I932).

52. 293 U. S. II2 (1934).

53. Senior v. Braden, 295 U. S. 422 (I935).

54. Pullman's Palace Car Co. v. Pennsylvania, I4I U. S. I8 (I89I) ; Frick v. Pennsylvania, 268 U. S. 473 (I925); City Bank Farmers' Trust Co. v. Schnader, 293 U. S. II2 (I934); Wheeling Steel Corp. v. Fox, 298 U. S. I93 (1936).

55. Safe Deposit \& Trust Co. v. Virginia, 280 U. S. 83 (I929).

56. Pullman's Palace Car Co. v. Pennsylvania, I4I U. S. I8 (I8gr); State Bd. of Assessors v. Comptoir National d'Escompte, I9I U. S. 388, 404 (Ig03); Buck v. Beach, 206 U. S. 392, 408 (I907); Frick v. Pennsylvania, 268 U. S. 473 (I925); Safe Deposit \& Trust Co. v. Virginia, 280 U. S. 83 (I929); Wheeling Steel Corp. v. Fox, 298 U. S. I93 (1936).

57. I99 U. S. I94 (1905).

58. See also Railroad Co. v. Jackson, 7 Wall. 262 (U. S. I869) ; State Tax on Foreign Held Bonds, I5 Wall. 300 (U. S. I873); Tappen v. Merchants' Nat'l Bank, I9 Wall. 490, 499 (U. S. I874) ; Delaware, L. \& W. R. R. v. Pennsylvania, I98 U. S. 34I (I905) ; Wheeling Steel Corp. v. Fox, 298 U. S. I93 (1936).

59. See New Orleans v. Stempel, I75 U. S. 309 (1899) ; Bristol v. Washington County, I77 U. S. I33 (I900); Metropolitan Life Ins. Co. v. New Orleans, 205 U. S. 395 (I907); Liverpool \& London Globe Ins. Co. v. Orleans Assessors, 22I U. S. 346 (IgII). 
erty right that a state cannot constitutionally burden it by a tax unless the physical property itself has a situs there. ${ }^{\text {Bo }}$

When we examine taxation realistically, it appears that jurisdiction to tax income does not differ materially from jurisdiction for purposes of other taxes. The state levies an ad valorem real property tax in return for the opportunities afforded by the possession of property; it levies an inheritance tax on land in return for the privilege of transmitting that property through death; and it levies an income tax on rents in return for the opportunities realized through the use of that property. The ultimate source of taxationthe property-is the same. In the case of the first two taxes, the Court has clearly and repeatedly declared that, regardless of the nomenclature applied to the tax, that state only within which the property has its situs can tax the property or any of its legal or economic incidents. Certainly it would seem that in the case of land, which is the sole source of the taxpayer's income from rents, the same considerations and the same emphasis on situs, demonstrated in ad valorem and inheritance tax cases, should have been adopted in respect to a tax upon the fruits of land. The same considerations that influenced the Court in those cases to enunciate a rule preventing multiple inheritance taxes on a single succession to property, despite the fact that such taxes operate but once, all the more would seem to justify a rule preventing multiple income taxation, which levies an annually recurring charge.

The application to income taxation of the attitude towards property and inheritance taxation would not seriously affect state revenues. Since the legal presumption of mobilia sequnntur personam requires the taxpayer to sustain the burden of proving a property situs elsewhere than at his domicile, then as a practical matter the rejection of the domiciliary state's claim to tax all income of its residents regardless of where it may be earned would have hampered but slightly the collection of revenues. In the cases of land and bona fide industrial or commercial transactions foreign situs is readily provable; in most individual enterprises the burden cannot be sustained. A contrary legal approach in the Cohn case would not only have resulted in greater logical consistency in tax theory but at the same time would have prevented discrimination against taxpayers who conduct interstate businesses in favor of those who limit their activities through multiple incorporation to their domiciliary states.

60. Frick v. Pennsylvania, 268 U. S. 473 (I925); City Bank Farmers' Trust Co. v. Schnader, 293 U. S. II2 (I934). In Farmers Loan \& Trust Co. v. Minnesota, 280 U. S. 204 (1930), the Court, citing its decisions on ad valorem property taxes, recognized the principle that choses in action may acquire a situs for taxation other than at the domicile of their owner if they have become integral parts of some local business. This proposition was reiterated in First Nat'1 Bank v. Maine, 284 U. S. 312 (I932). In both of these cases, however, the record indicated that the intangibles therein were economically integrated at their owners' domicile; and consequently the Court was not there called upon to delimit the jurisdiction of the domiciliary state over death taxes on intangibles. 


\section{III}

While the Court has carefully sustained in the above rather extreme cases the right of both states to levy income taxes where the two jurisdictional elements-domicile of the taxpayer and situs of the property basis of the income-are divided between them, the same tribunal has, on the other hand, gone to opposite extremes in barring the states from levying income taxes upon the salaries of employees of federal governmental instrumentalities. The legal and social concepts that determined the first two decisions discussed were conspicuously absent here. Apparently the field of state income taxation is henceforth to be divided into two broad categories-the one conflicts, however real, between the states, and the other conflicts, however fictitious, between the state and federal governments. And to each compartment must be applied a totally different set of socio-economic objects, of jurisdictional concepts, and of logical processes.

The case of Rogers $v$. Graves ${ }^{61}$ involved the right of New York to tax a resident on that part of his income secured as salary as general counsel of a federally owned corporation. The Panama Railroad Company was incorporated by private capital in New York for the purpose of constructing and operating a railroad across the Isthmus of Panama. When the United States acquired control of the Panama Canal Zone and the right to construct a ship canal across it, the Federal Government purchased the entire capital stock of the Panama Railroad Company. It elects the board of directors of the corporation. The company now operates a railroad across Panama, conducts a commissary establishment for the Canal civil and military personnel, and operates two hotels, a dairy, and a steamship line between New York and the Canal Zone. These various activities, the Court declared, are used chiefly as "adjuncts" to the management and operation of the canal and hence are all governmental functions within the congressional power to provide for the national defense and the regulation of commerce.

A unanimous court, speaking through Mr. Justice Sutherland, found no great difficulty in determining that the Panama Railroad Company was a federal instrumentality, constitutionally free from interfering state taxation. From that proposition the Court deftly hurdled the barriers of logic and suavely repeated the oft exploded non-sequitur that a tax on the income of an employee of a governmental instrumentality is a burden on the instrumentality itself.

"The railroad company being immune from state taxation, it necessarily results that fixed salaries and compensation paid to its officers and employees in their capacity as such are likewise immune." $\mathbf{6 2}^{\mathbf{2}}$

6r. 57 Sup. Ct. 269 (1937).

62. Id. at 272 . 
The Court failed to explain why its conclusion "necessarily results". Why does it necessarily follow that a state tax on a resident employed by a federal instrumentality, measured in part by his salary therefrom, is a tax upon the instrumentality itself; while it does not follow that a state tax on a resident, owning land in another state, measured in part by his income from that land, is a tax upon the land? By what pragmatic or conceptual test is the former a legal sequitur, and the latter a legal non-sequitur?

The possible explanation for the distinction is the long line of precedents against state income taxation of federal employees built upon an original misconception of Chief Justice Marshall's decision in McCulloch $v$. Maryland. ${ }^{63}$ In that case, the state of Maryland, giving expression to the then current agrarian animosity against the Bank of the United States, ${ }^{64}$ levied a stamp tax on the notes issued by banks within the state not chartered by its legislature. Beyond any doubt this statute discriminated against the bank chartered by Congress to assist the federal government in the execution of its constitutional powers; in fact, the undoubted purpose of the state legislation was to drive the branch of the bank out of the state. Marshall, instead of examining into the purpose of the Maryland tax and invalidating it as a direct attempt of the state to interfere with a federal function, resorted rather to the concept of universality then prevalent in jurisprudence and laid down the broad proposition that a state cannot in any manner tax an instrumentality of the federal government. The reasoning employed in the $M c C$ ulloch opinion made no attempt to differentiate among different exercises of the taxing power, among the various sorts of government instrumentalities, nor among the possibly divergent purposes of the state tax. Employing the language of universality, the Court declared that "If the States may tax one instrument, employed by the government in the execution of its powers, they may tax any and every other instrument." ${ }^{65}$ This power to tax any instrumentality could not be permitted because "the power to tax involves the power to destroy; . . . the power to destroy may defeat and render useless the power to create; .. . there is a plain repugnance, in conferring on one government a power to control the constitutional measures of another, which other, with respect to those very measures, is declared to be supreme over that which exerts the control . . ."66 The opinion totally disregarded the discriminatory aspect of the state law and definitely implied that even a non-discriminatory tax on the bank would have been held unconstitutional. ${ }^{67}$

63. 4 Wheat. 3 I6 (U. S. r8rg).

64. 4 Beveridge, Life of JoHn Marshall (I9I9) I96-9, 206-8.

65. 4 Wheat. 316, 432 (U. S. I8I9).

66. Id. at $43 \mathrm{I}$.

67. Today by federal statute states may tax national banks at the same rates as they tax state banks. Cf. North Dakota v. Olson, 33 F. (2d) 848 (C. C. A. 8th, 1929), in which the Federal Government succeeded in collecting a non-discriminatory tax from a state-owned bank. 
Today, inasmuch as the principal means of financing governmental expenditures are income and excise taxes and since these taxes do not discriminate against governmental instrumentalities, the real problem of the $M c C$ ulloch case is no longer significant. The Supreme Court, however, has somehow failed to recognize the pragmatic basis of Marshall's decision and has blindly followed his conceptionalistic rationalization. Unless it is convinced that the governmental instrumentality is engaged in a proprietary rather than a governmental function, the Court strikes down the tax, even though the very structure of an income tax prevents its use as a discriminatory device. And somehow the instrumentalities of the federal government are more likely to be classified as governmental than are like activities of the state governments.

Instead of frankly abandoning the Marshall tradition, the Court has endeavored to circumvent the difficulties arising from the expansion of governmental work by minute refinements in its concept of a governmental instrumentality. Government securities are instrumentalities for financing the excess of governmental expenditures over tax receipts and hence may not be taxed nor their incomes taxed by another unit of government. ${ }^{68}$ Government-owned corporations, created to carry out federal functions, are likewise exempt. ${ }^{69}$ And the application of the theory is carried to the extent of holding that employees of governmental departments or corporations are tax-exempt instrumentalities. ${ }^{70}$ If, however, the degree of relationship between the alleged instrumentality and the execution of a government function is remote, then the Court may hold that the taxpayer is not a government instrumentality or agent and that, therefore, the Marshall rule of exemption need not be applied. Thus the states have been permitted to tax the interest of a corporation in a dry dock which the United States had the right to use under a contract with the corporation, ${ }^{71}$ and to tax the premium collected by a bonding insurance company on surety bonds required of United States officials. ${ }^{2}$ And, after vigorous judicial controversy, the states may now tax the incomes derived from federal patents and copyrights. ${ }^{73}$ It is important to note that, in its attempts to determine the degree of rela-

68. Weston v. Charleston, 2 Pet. 449 (U. S. I829) ; Pollock v. Farmers' Loan \& Trust Co., I57 U. S. 429 (I895); Farmers and Mechanics Savings Bank v. Minnesota, 232 U. S. 5 I6 (I9I4); Miller v. Milwaukee, 272 U. S. 713 (I927); Anderson, The Problem of TaxExempt Securities (I924) 8 MINN. L. REv. 273.

69. King County v. United States Shipping Bd. Emer. Fleet Corp., 282 Fed. 950 (C. C. A. 9th, I922) ; United States Spruce Production Corp. v. Lincoln County, 285 Fed. 388 (D. Ore. 1922); Clallam County v. United States Spruce Production Corp., 263 U. S. 34I (1923).

70. Dobbins v. Commissioners of Erie County, I6 Pet. 435 (U. S. I842); Collector v. Day, II Wall. II3 (U. S. I87I); Magill, Tax Exemption of State Employees (I926) 35 YALE L. J. 956.

7I. Baltimore Shipbuilding Co. v. Baltimore, 195 U. S. 375 (1904).

72. Fidelity \& Deposit Co. v. Pennsylvania, 240 U. S. 319 (19I6).

73. Educational Films Corp. v. Ward, 282 U. S. 379 (I93I) ; Fox Film Corp. v. Doyal, 286 U. S. I23 (I932); $c f$. Long v. Rockwood, 277 U. S. I42 (I928). 
tionship between the taxpayer and the government or in its differentiation between purely governmental and proprietary functions, the Supreme Court has made exceptions to the Marshall doctrine much more frequently to enable the Federal Government to tax the new activities of the states than to permit parallel state taxation of the new federal activities. In sharp contrast to the Rogers case are Metcalf $\&$ Eddy v. Mitchell, ${ }^{74}$ holding that the Federal Government could collect income taxes on fees paid to consulting engineers by states and municipal corporations for advising them concerning proposed water supply and sewage disposal systems, South Carolina v. United States ${ }^{75}$ and Ohio $v$. Helvering, ${ }^{76}$ sustaining federal license taxes upon state liquor dispensaries, and Helvering $v$. Powers, ${ }^{77}$ upholding federal income taxes on the salaries of officials of a state utility.

Upon the unproven theory that state income taxation of the salaries of federal employees would compel the national government to raise the pay of its employees and officers or would prevent it from securing competent personnel, such taxation is unconstitutional. The Rogers decision, invalidating an income tax that in nowise discriminated ever so mildly against the federal government or its personnel, is a far cry from the discriminatory state tax that Marshall properly rejected. And it is an even farther call from the phraseology of the Constitution, which nowhere expressly or impliedly requires that a federal employee shall not pay to the state of his domicile a fair share of his income for that "protection" which Mr. Justice Stone insisted in the Cohn case is a necessary concomitant of such domicile.

\section{IV}

Regardless of our estimation of their legal and practical results, the current decisions of the Supreme Court have gone far in clarifying the powers of the states to finance themselves through income taxes. In the first place, no state, domiciliary or non-domiciliary, can tax the incomes of, or derived from, federal instrumentalities. Unless Congress specifically so provides, the states cannot share in the profits earned by the many new federal corporations, even where such agencies take over private corporations which were previously subject to state income taxation. And further the states cannot

74. 269 U. S. 514 (I926).

75. I99 U. S. 437 (I905). On the basis of this precedent the Eighth Circuit Court of Appeals held that the Federal Government can tax under its capital stock tax statute a bank created, owned, and operated by the state of North Dakota as an essential link in its nonpartisan program. North Dakota v. Olson, 33 F. (2d) 848 (C. C. A. Sth, 1929).

76. 292 U. S. 360 (1934). "Whenever a state engages in a business of a private nature, it exercises non-governmental functions, and the business, though conducted by the state, is not immune from the exercise of the power of taxation which the constitution vests in the Congress." At 368 . "When a state enters the market place seeking customers it divests itself of its quasi-sovereignty pro tanto, and takes on the character of a trader, so far at least as the taxing power of federal government is concerned." At 369 .

77. 293 U. S. 214 (1934). 
tax the salaries of the increasing army of federal employees or employees of federal corporations.

In the second place, no limits are placed upon domiciliary state income taxation of its own residents. A state may tax all the incomes earned by its residents within its borders, except that derived from a federal security or instrumentality. This power includes the taxation of the net proceeds from interstate commerce. ${ }^{78}$ A state may similarly tax without constitutional restraint, so long as the tax is not discriminatory, ${ }^{79}$ all incomes earned by its residents outside that state. Such non-local income may be rents, ${ }^{80}$ personal services, ${ }^{81}$ or trust proceeds. ${ }^{82}$

And thirdly, the states are given broad powers to tax the incomes earned within their borders by residents of other states. The only limitation is that the taxing state show with a fair degree of reasonableness that the income taxed was earned within the state. ${ }^{83}$ Non-domiciliary taxing power covers income from personal services within the state, ${ }^{84}$ from sale of property located in or associated with the state, ${ }^{85}$ from natural resources within the state, ${ }^{86}$ or from manufacturing or sale of commodities within the state. ${ }^{87}$ Just as a state in levying franchise taxes on foreign corporations doing business within the state may measure the tax by the corporate property or business within the state ${ }^{88}$ or by the corporate income from business conducted within the state, ${ }^{89}$ so likewise it may directly levy an income tax on the corporate profits from business transactions within the state. ${ }^{90}$

What of the future? Undoubtedly, many states possessing income tax laws will promptly amend their statutes, conforming to the New York legislation sustained in the Cohn and Whitney cases, to cover specifically incomes of its residents from foreign rents and of non-residents from local business enterprises.

78. United States Glue Co. v. Oak Creek, 247 U. S. 32I (I9I8).

79. Colgate v. Harvey, 296 U. S. 404 (I935).

80. Cohn v. Graves, 57 Sup. Ct. 466 (I937), 85 U. of PA. L. Rev. 645.

8I. Lawrence v. State Tax Comm., 286 U. S. 276 (I932).

82. Maguire v. Trefry, 253 U. S. I2 (Ig20).

83. On the problem of allocation of local and non-local incomes, see Underwood Typewriter Co. v. Chamberlain, 254 U. S. II3 (I920) ; Bass, Ratcliffe \& Gretton v. State Tax Comm., 266 U. S. 27I (I924); Hans Rees Sons v. North Carolina, 283 U. S. I23 (I93I); Huston, Allocation of Corporate Net Income for Purposes of Taxation (I932) 26 ILL. L. REV. 725 .

84. Travis v. Yale \& Towne Mfg. Co., 252 U. S. 60 (I920).

85. Whitney v. Graves, 57 Sup. Ct. 237 (1937).

86. Shaffer v. Carter, 252 U. S. 37 (I920).

87. Underwood Typewriter Co. v. Chamberlain, 254 U. S. Ir3 (1920) ; Hans Rees Sons v. North Carolina, 283 U. S. I23 (I93I).

88. Western Union Tel. Co. v. Kansas, 2I6 U. S. I (I9I0) ; Provident Savings Life Ass. Soc. v. Kentucky, 239 U. S. I03 (I9r5) ; Looney v. Crane Co., 245 U. S. I78 (I9I7) ; International Paper Co. v. Massachusetts, 246 U. S. I35 (rgr8); Cudahy Packing Co. v. Kinkle, 278 U. S. 460 (I929).

89. Underwood Typewriter Co. v. Chamberlain, 254 U. S. II3 (I920) ; Bass, Ratcliff \& Gretton v. State Tax Comm., 266 U. S. 27 I (I924).

90. Hans Rees Sons v. North Carolina, 283 U. S. 123 (I93I). 
To date most states tax domestic corporations only upon income from local sources. But now with the emphasis focused on domiciliary protection, no legal reason remains why domiciliary states should not amend their statutes to tax all the income of their domestic corporations, regardless of the place where the income is earned. Nowhere has the Court in its discussions of domiciliary income taxation indicated a difference between individual and corporate residents. Thus the state of incorporation may validly tax the incomes of domestic corporations-even though the "main office" of the corporation may be a file hidden away in some law or trust company office. Such tax may cover profits from manufacturing, sales, or patent licenses all performed in some other state. Undoubtedly the enactment of such sweeping income tax reforms would be followed by attempts to avoid the new levies by multiple incorporation; and, in turn, the courts will probably permit piercing the corporate entities in order to circumvent such tax avoidance techniques. ${ }^{91}$

The Court's recent decisions similarly permit state statutory amendments that would tax trust incomes if the recipient of the income or the situs of the trust is in the taxing state. At least one state ${ }^{92}$ already subjects trust income to local taxation if the settlor or the trustee or the beneficiary or the trust res is situated within the state. The enactment of similar legislation by other commonwealths would render quadruple taxation of trust incomes an actuality and would go far towards destroying the trust device.

9I. See Palmolive Co. v. Conway, 43 F. (2d) 226 (W. D. Wis. I930), aff'd, 56 F. (2d) 83 (C. C. A. 7th, I932) ; Buick Motor Co. v. Milwaukee, 43 F. (2d) 385 (E. D. Wis. I930), aff'd, 48 F. (2d) $80 \mathrm{I}$ (C. C. A. 7th, 193I), cert. denied, 284 U. S. 655 (I93I).

92. Codes, Laws and Const' AMends. of CaL. (Deering, Supp. 1935) p. 1979. 